\title{
Drie jaar nieuwe arbitragewet: tien suggesties voor verbetering
}

\author{
Niek Peters*
}

\section{Inleiding}

De nieuwe arbitragewet is per 1 januari 2015 in werking getreden. Met de nieuwe wet is beoogd om onduidelijkheden in de arbitragewet van 1986 op te heffen en belemmeringen voor het gebruik van arbitrage weg te nemen. Arbitrage zou daardoor efficiënter worden. Verder beoogde de wetgever de Nederlands concurrentiepositie te verbeteren. Dat zou economische voordelen meebrengen, zoals (1) inkomsten voor arbitrage-instituten in Nederland, (2) inkomsten voor advocaten die de partijen bijstaan in het arbitraal geding of over een geding adviseren, en (3) inkomsten voor de lokale economie in steden die als plaats van arbitrage worden gekozen. ${ }^{1}$

Internationaal gezien heeft de invoering van de nieuwe arbitragewet weinig aandacht gekregen. ${ }^{2}$ Nederland is bovendien niet het enige land waar de arbitragewet de afgelopen jaren is herzien en andere landen, zoals bijvoorbeeld Duitsland, Zweden en Zwitserland, bereiden herzieningen voor. ${ }^{3}$ Waar de arbitragewet van 1986 bij zijn invoering onderscheidend en innovatief was, geldt dat voor de nieuwe wet vergeleken met buitenlandse arbitragewetten niet of nauwelijks en de nieuwe arbitragewet wijkt op onderdelen bovendien af van buitenlandse arbitragewetten. ${ }^{4}$ Nederland behoort in ieder geval niet tot de populairste plaatsen van arbitrage. Volgens een recent onderzoek van de School of International Arbitration van Queen Mary University of London zijn Londen, Parijs, Singapore, Hong Kong en Genève het populairst. ${ }^{5}$ In 2010 waren

Mr. N. Peters is advocaat te Amsterdam bij Cleber en docent aan de Rijksuniversiteit Groningen.

1. Kamerstukken II 2012/13,33611,3, p. 1-2 (MvT).

2. Ook de wijzigingen die de DIS, ICC, SCC, SIAC en VIAC de afgelopen jaren in hun arbitragereglement hebben doorgevoerd, hebben internationaal meer aandacht getrokken dan de wijzigingen die de Nederlandse arbitrage-instituten naar aanleiding van de wetswijziging in 2015 in hun reglementen hebben doorgevoerd. Wat dat betreft kan men wel stellen dat de Nederlandse instituten internationaal weinig zichtbaar zijn.

3. Hierbij is nog vermeldenswaardig dat in de Verenigde Staten een Restatement on the Law of International Commercial and Investment Arbitration, waarin de taak van de rechter in verband met arbitrage wordt omschreven, wordt voorbereid door een werkgroep onder leiding van prof. G.A. Bermann.

4. Zie hieromtrent ook G.J. Meijer, 'De nieuwe Arbitragewet (2015) bezien in het licht van internationale arbitrage', in: Arbitragerecht, op de scheidslijn van oud naar nieuw (reeks NVvP, deel 30), Den Haag: Boom juridisch 2015 (hierna: Meijer 2015), p. 89-90.

5. Zie www.arbitration.qmul.ac.uk/media/arbitration/docs/2018-Internati onal-Arbitration-Survey---The-Evolution-of-International-Arbitration(2).PDF. dat Londen, Parijs, New York en Genève. ${ }^{6}$ Volgens voornoemde onderzoeken kiest men hoofdzakelijk voor deze plaatsen vanwege hun reputatie, de aanwezige (juridische) infrastructuur, de aanwezigheid van toegankelijke, neutrale en onpartijdige rechtspraak, de toepasselijke arbitragewet en het positieve track record als het gaat om de afdwingbaarheid van arbitrageovereenkomsten en arbitrale vonnissen. ${ }^{7}$ Hoewel men de waarde van voornoemde onderzoeken niet moet overschatten - het is immers niet zonder meer gegeven dat een representatieve groep personen heeft gerespondeerd - kan wel worden geconcludeerd dat Singapore en Hong Kong de afgelopen jaren aan populariteit hebben gewonnen. Dat kan op basis van openbare informatie niet van Nederland worden gezegd. ${ }^{8}$ Evenmin kan worden geconcludeerd dat er hier te lande thans arbitrages plaatsvinden die hier onder de oude arbitragewet niet hadden plaatsgevonden. Wat dat betreft had Snijders een vooruitziende blik, toen hij in 2013 stelde dat het niet in de rede lag om aan te nemen dat Nederland met de nieuwe arbitragewet enorme sprongen zou maken op de ranglijst van populaire arbitrageplaatsen. ${ }^{9}$

Verder kan niet worden geconcludeerd dat arbitrage door de invoering van de huidige arbitragewet een interessanter alternatief is geworden voor overheidsrechtspraak. Hoewel steeds meer mensen de gang naar de rechter te duur, te ingewikkeld en te ongewis vinden ${ }^{10}$ en lange doorlooptijden een bron van ergernis zijn, heeft dat niet geresulteerd in een substantiële toename van het aantal arbitrages sinds 1 januari

6. Zie www.arbitration.qmul.ac.uk/media/arbitration/docs/2010_Internati onalArbitrationSurveyReport.pdf.

7. Uit bijvoorbeeld de meest recente statistieken van de ICC komt eenzelfde beeld naar voren. Zie https://cdn.iccwbo.org/content/uploads/sites/ 3/2018/07/2017-icc-dispute-resolution-statistics.pdf.

8. Uit de eerdergenoemde rapporten kan niet worden afgeleid dat Nederland als plaats van arbitrage populairder is geworden. Ook kan dat niet worden afgeleid uit de jaarverslagen van arbitrage-instituten. Van de 810 nieuwe zaken die in 2017 bijvoorbeeld bij de ICC werden aangemeld, lag de plaats van arbitrage 9 keer in Nederland. Dit getal is al jaren ongeveer gelijk en valt in het niet bij het aantal keren dat bijvoorbeeld Parijs (121), Londen (73), Genève (51), Singapore (38), Zürich (36), New York (28) of Hong Kong (18) als plaats van arbitrage was aangewezen. Voor arbitrages die werden geadministreerd door de LCIA, SCC en DIS lag de plaats van arbitrage in 2017 geen enkele keer in Nederland. Voor zover ik heb kunnen nagaan, was dat in voorgaande jaren niet wezenlijk anders.

9. H.J. Snijders, 'Algemene beschouwingen bij het Wetsvoorstel Modernisering Arbitragerecht', TvA 2013/31, p. 94.

10. Jaarverslag Rechtspraak 2017, te raadplegen via: https:// jaarverslagrechtspraak.nl/pagina/jaarbericht. 
2015, althans daarvan blijkt niet uit openbare informatie van bijvoorbeeld het Nederlands Arbitrage Instituut (NAI), ${ }^{11}$ de Raad van Arbitrage voor de Bouw (RvA), ${ }^{12}$ de Stichting Raad van Arbitrage voor Metaalnijverheid en - Handel $^{13}$ of het Scheidsgerecht Gezondheidszorg. ${ }^{14}$ Wellicht heeft het ermee te maken dat arbitrage ook blootstaat aan soortgelijke beschouwingen. Veelgehoorde kritieken zijn immers nog steeds dat partijen de arbitrage (flink) kunnen vertragen of compliceren, dat exequatur- en vernietigingsprocedures lang kunnen duren, en dat het allemaal best prijzig is. ${ }^{15}$

Daarbij komt dat vanuit de hoek van de overheidsrechtspraak alternatieven voor arbitrage worden opgezet. Ik denk hier bijvoorbeeld aan de Netherlands Commercial Court (of Appeal) ${ }^{16}$ (NCC(A)) en andere buitenlandse commercial courts, zoals in Parijs, Singapore en Dubai. In andere landen wordt aan soortgelijke alternatieven gewerkt. In België bestaat bijvoorbeeld het voornemen om de Brussels International Business Court (BIBC) op te richten. ${ }^{17} \mathrm{Net}$ als bij de NCC(A) is de voertaal Engels en wordt in het Engels uitspraak gedaan. Vergeleken met de NCC(A) is interessant dat in België op dit moment de gedachte leeft om de procedure bij de BIBC in beginsel te enten op de UNCITRAL Model Law on International Commercial Arbitration (de Modelwet), dat de BIBC niet alleen zal bestaan uit rechters, maar ook uit experts van buiten de rechtspraak, en dat hoger beroep niet mogelijk is. Niet valt uit te sluiten dat partijen die eerder arbitrage overwogen, nu zullen opteren voor een commercial court. Dat geldt te meer als de vonnissen van de commercial courts internationaal ook (eenvoudig) uitvoerbaar zullen zijn, bijvoorbeeld op grond van de Brussel Ibis-Verordening of het Haags Forumkeuzeverdrag. Vooralsnog geldt laatstgenoemd verdrag slechts voor een beperkt aantal landen, ${ }^{18}$ maar als meer landen partij worden bij dit verdrag of de EU, dan zullen rechterlijke uitspraken in steeds meer landen worden erkend en op betrekkelijk eenvoudige wijze ten uitvoer kunnen worden gelegd, net zoals een arbitraal vonnis op grond van het Verdrag van New York (NYC) betrekkelijk eenvoudig kan worden erkend en

11. De jaarverslagen van het NAI melden voor de periode 2009-2017 het volgende aantal nieuwe arbitrages per jaar: 145, 125, 147, 109, 114, 112, 99,81 en 98 .

12. Uit de jaarverslagen van de RvA voor de periode 2009-2015 blijkt een daling van het aantal arbitrages van ongeveer 1300 nieuwe zaken per jaar naar minder dan 1000 zaken per jaar.

13. De jaarverslagen van de Stichting Raad van Arbitrage voor Metaalnijverheid en -Handel melden voor de periode 2009-2016 het volgende aantal nieuwe arbitrages per jaar: 40, 35, 25, 15, 14, 16, 10 en 13 .

14. De jaarverslagen van het Scheidsgerecht Gezondheidszorg melden voor de periode 2013-2017 het volgende aantal nieuwe arbitrages per jaar: 45, $36,23,27$ en 26.

15. Zie hieromtrent onder meer voornoemde onderzoeken van de School of International Arbitration.

16. Zie hierover D.J. Oranje, 'The coming into being of the Netherlands Commercial Court', TCR 2016, afl. 4, p. 122-126, P.E. Ernste \& F.E. Vermeulen, 'The Netherlands Commercial Court - an attractive venue for international commercial disputes?', TCR 2016, afl. 4, p. 127-137 en E. Bauw, H. Koster \& S.A. Kruisinga (red.), De kansen voor een Netherlands Commercial Court, Den Haag: Boom juridisch 2018.

17. Zie voor het relevante wetsvoorstel www.lachambre.be/FLWB/PDF/54/ 3072/54K3072001.pdf.

18. Zie www.hcch.net/en/instruments/conventions/status-table/?cid=98. ten uitvoer kan worden gelegd. ${ }^{19}$ Als gerechtelijke uitspraken inderdaad in steeds meer landen kunnen worden erkend en ten uitvoer kunnen worden gelegd, kan arbitrage op den duur een van haar grootste voordelen ten opzichte van overheidsrechtspraak verliezen.

In het licht van het voorgaande zal de toekomstbestendigheid van arbitrage vooral zijn gewaarborgd als kort gezegd een flexibele, efficiënte en met voldoende waarborgen omklede procedure wordt geboden, waarbij de inmenging van de overheidsrechter minimaal is, de vertrouwelijkheid geborgd blijft en het arbitraal vonnis eenvoudig ten uitvoer kan worden gelegd. ${ }^{20}$ Met dit in het achterhoofd doe ik hierna (mede met het oog op een eventuele evaluatie van de nieuwe arbitragewet) tien suggesties. Daarbij heb ik vooral gedacht aan handelsgeschillen, maar dat brengt niet noodzakelijkerwijze mee dat deze suggesties niet ook bij andersoortige geschillen, zoals consumenten- en investeringsgeschillen, een meerwaarde zouden kunnen hebben.

\section{De tien suggesties}

In het vervolg van dit artikel zal ik de tien suggesties uiteenzetten.

\subsection{Regel aantal arbiters en wijze van benoeming}

Als partijen geen afspraak hebben gemaakt over het aantal arbiters en zij de zeggenschap over de bepaling van het aantal arbiters evenmin rechtsgeldig hebben overgedragen aan een derde, zoals bijvoorbeeld een arbitrage-instituut, althans deze derde zijn opdracht niet uitvoert, dan kan de meest gerede partij zich ingevolge art. 1026 lid $2 \mathrm{Rv}$ tot de voorzieningenrechter wenden. ${ }^{21}$ Deze bepaalt dan het aantal arbiters. In de regel gaan hier enkele weken tot maanden overheen. ${ }^{22}$ De arbitrage loopt aldus vertraging op. Ook leidt deze rechterlijke inmenging tot extra kosten. Dat is onnodig. De wet kan namelijk eenvoudig het aantal arbiters bepalen, bijvoorbeeld één of drie. Bij de invoering van de nieuwe arbitragewet is hierover niet nagedacht en internationaal gezien loopt Nederland met de huidige regeling uit de pas. In ons omringende landen voorziet de arbitragewet namelijk in een aantal arbiters. Behoudens andersluidende afspraken bestaat het scheidsgerecht in Engeland bijvoorbeeld uit één arbiter. ${ }^{23}$ In België ${ }^{24}$ en Duitsland ${ }^{25}$ geldt dat het scheidsgerecht zal bestaan uit drie arbiters. Dat is ook het uitgangspunt in de Modelwet. ${ }^{26}$ Vanwege proceseconomische redenen en lagere kosten (één arbiter is nu eenmaal goedkoper dan drie arbiters) gaat mijn persoonlijke voorkeur

19. Op dit moment zijn 159 landen partij bij het Verdrag van New York.

20. Zie bijv. de onderzoeken van de School of International Arbitration voor de voornaamste motieven om te kiezen voor arbitrage.

21. Art. 1026 lid 2 Rv is bij wet van 1986 geïntroduceerd.

22. Volledigheidshalve zij hierbij opgemerkt dat ingevolge art. $1070 \mathrm{Rv}$ geen hoger beroep openstaat.

23. Art. 15 lid 3 English Arbitration Act 1996 (EAA).

24. Art. 1684 lid 3 Belgisch Gerechtelijk Wetboek (BGW).

25. Art. 1034(1) Zivilprozessordnung (ZPO).

26. Art. 10 lid 2 Modelwet. 
uit naar de Engelse oplossing. ${ }^{27}$ Ik zou dan ook willen voorstellen wettelijk te verankeren dat bij gebreke van een andersluidende afspraak het scheidsgerecht bestaat uit één arbiter.

Verder dient art. 1027 lid $1 \mathrm{Rv}$ - dat in 1986 is ingevoerd en dat in de nieuwe arbitragewet eveneens ongewijzigd is geble$v^{2}{ }^{28}$ - te worden aangepast. Op grond van dat artikel moeten de arbiters, ook wanneer het scheidsgerecht uit drie of meer arbiters bestaat, bij gebreke van een andersluidende afspraak, door de partijen gezamenlijk worden benoemd. Dat blijkt in de praktijk nogal eens lastig. Het gebeurt namelijk geregeld dat partijen het niet eens kunnen worden, in welk geval de meest gerede partij zich tot de rechter moet wenden voor de benoeming van de arbiters. Dat is vrij omslachtig. Het verdient dan ook aanbeveling om de wet in die zin aan te passen, dat bij een scheidsgerecht dat uit drie of meer arbiters bestaat elk van de partijen een gelijk aantal arbiters kan benoemen en dat de aldus benoemde arbiters de voorzitter kiezen. Zodoende hoeven partijen het niet met elkaar eens te worden over de samenstelling van het gehele scheidsgerecht, hetgeen de kansen op gerechtelijke inmenging verkleint. Zo'n regeling kent men bijvoorbeeld in Engeland ${ }^{29}$ en Frankrijk. ${ }^{30}$

\subsection{Expliciteer het vertrouwelijke karakter van arbitrage}

Vertrouwelijkheid wordt veelal gezien als een voordeel van arbitrage en partijen kiezen mede hierom voor arbitrage. ${ }^{31}$ Ook bij het bepalen van de plaats van arbitrage lijkt vertrouwelijkheid een factor te zijn. In Nederland wordt vertrouwelijkheid (met inbegrip van de daarmee verband houdende geheimhoudingsplicht) in beginsel als een vast kenmerk en beginsel van ongeschreven Nederlands arbitragerecht beschouwd..$^{32}$ Niet in alle landen is vertrouwelijkheid evenwel steeds het uitgangspunt. ${ }^{33}$ Vanwege deze ontwikkeling opperde Van den Berg in 2005 in zijn ontwerp voor een nieuwe arbitragewet $^{34}$ - welk ontwerp aan de wieg heeft gestaan van de nieuwe wet - de volgende bepaling voor vertrouwelijkheid:

'Een arbitrage is vertrouwelijk en alle direct en indirect betrokken personen zijn gehouden tot geheimhouding, behoudens en voor zover openbaarmaking uit de wet of de overeenkomst van partijen voortvloeit.'

27. Zie hieromtrent nader N. Peters, The fundamentals of international commercial arbitration, Antwerpen/Apeldoorn: Maklu 2017 (hierna: Peters 2017), p. 128.

28. Uit de parlementaire geschiedenis kan niet worden afgeleid dat bij de invoering van de nieuwe arbitragewet is nagedacht over dit artikel.

29. Art. 16 lid 3 EAA.

30. Art. 1452 lid 2 Code de procédure civil (CPC).

31. Zie bijv. Kamerstukken II 2012/13, 33611, 3, p. 3 (MvT).

32. Zie H.J. Snijders, 'Arbitrage, vertrouwelijkheid of openbaar mixtum daarvan', TvA 2014/1 (hierna: Snijders 2014), p. 1, met een verwijzing naar andere literatuur.

33. Zie onder meer Snijders 2014, p. 2.

34. 'Tekst van de Voorstellen tot wijziging van het Vierde Boek (Arbitrage), artikelen 1020-1076 Rv', TvA 2005/36.
Gelijk voornoemd ontwerp werd in de eerste (consultatie)voorstellen van de nieuwe arbitragewet voorzien in vertrouwelijkheid van arbitrage. In het voorstel van wet is dit geschrapt. Het was echter onduidelijk waarom de wetgever zich had bedacht. Naar aanleiding van vragen van de Tweede Kamerfractie van de VVD is toegelicht dat geen bepaling voor vertrouwelijkheid was opgenomen gezien het advies van de Nederlandse Vereniging voor Rechtspraak, dat van vertrouwelijkheid misbruik zou kunnen worden gemaakt. ${ }^{35}$ De Eerste Kamerfractie van het CDA was vervolgens uiterst kritisch dat de bepaling voor vertrouwelijkheid was geschrapt enkel op basis van voornoemd advies. ${ }^{36}$ Hierop heeft de minister bij memorie van antwoord uiteengezet dat arbitrages - met uitzondering van arbitrages met een publiekrechtelijk gehalte, zoals investeringsarbitrages - zijns inziens zonder wettelijke regeling in beginsel ook vertrouwelijk zijn. Omdat een wettelijke vertrouwelijkheidsregeling niet eenvoudig te formuleren zou zijn, wilde de minister de vertrouwelijkheid evenwel niet wettelijk verankeren. ${ }^{37}$ Het niet in de wet opnemen van vertrouwelijkheid is mijns inziens een gemiste kans. ${ }^{38} \mathrm{Zo}$ is bij een enkele bestudering van onze arbitragewet thans niet duidelijk dat arbitrage vertrouwelijk is. Bovendien blijft de omvang van de vertrouwelijkheid in het midden. Ongewis is bijvoorbeeld ten aanzien van welke informatie de vertrouwelijkheid geldt, wie verplicht is tot vertrouwelijkheid en ten opzichte van wie informatie vertrouwelijk moet worden gehouden.

Verder zijn procedures bij de overheidsrechter met betrekking tot arbitrage in beginsel niet vertrouwelijk, maar openbaar. In de toelichting op de hiervoor geciteerde passage stelde Van den Berg dat het beginsel van vertrouwelijkheid zijns inziens ook van toepassing zou moeten zijn op procedures bij de overheidsrechter die op arbitrage betrekking hebben. ${ }^{39}$ Met zo'n regeling was tegemoetgekomen aan een behoefte vanuit de praktijk. Het vertrouwelijke karakter van arbitrage wordt nu immers uitgehold wanneer een procedure bij de overheidsrechter wordt geëntameerd, bijvoorbeeld voor de benoeming van arbiters, ter vernietiging van het arbitraal vonnis of in strijd met de arbitrageovereenkomst. Zo gebeurt het nu geregeld dat de rechtszaal afgeladen is met derden, onder wie journalisten, als het om spraakmakende kwesties gaat.

Ofschoon partijen afstand kunnen doen van het recht op een openbare behandeling, kan vertrouwelijkheid van gerechtelijke procedures bij gebreke van een wettelijke regeling mogelijk niet in alle gevallen worden gegarandeerd, omdat op grond van vaste rechtspraak van het Europees Hof voor de Rechten van de Mens (EHRM) de 'waiver (...) must not run counter to any important public interest' en de rechter wat dat betreft een

\footnotetext{
35. Kamerstukken II $2013 / 14,33611,5$, p. 8 (NV).

36. Kamerstukken I 2013/14, 33611, B, p. 2 (VV).

37. Zie uitgebreid Kamerstukken I 2013/14, C, p. 2-4 (MvA).

38. Zie hierover ook F. De Ly, 'Het Wetsvoorstel modernisering van het arbitragerecht en de internationale arbitrage', TvA2013/38, p. 147-149.

39. 'Toelichting op de Voorstellen tot wijziging van het Vierde Boek (Arbitrage)', $T v A 2005 / 37$, p. 174-175.
} 
eigen verantwoordelijkheid heeft. ${ }^{40}$ Het zou derhalve goed zijn als de wetgever duidelijkheid schept en tegemoetkomt aan de wensen van de gebruikers van arbitrage. Zittingen bij de gewone rechter die verband houden met arbitrage kunnen dan met gesloten deuren plaatsvinden, met alle bijkomende voordelen van dien. Gezien de rechtspraak van het EHRM bestaat op dit moment geen reden om te veronderstellen dat een regeling waarbij de wetgever voorschrijft dat gerechtelijke procedures die verband houden met arbitrage, behoudens een andersluidende overeenkomst van partijen, met gesloten deuren plaatsvinden, principieel in strijd is met art. 6 van het Europees Verdrag tot bescherming van de rechten van de mens en de fundamentele vrijheden (EVRM). Wat dat betreft is het ook geen probleem dat met de voorgestelde regeling wordt gederogeerd aan art. $27 \mathrm{Rv}$. Van uitspraken die met gesloten deuren zijn behandeld, kan een geanonimiseerd afschrift of uittreksel worden gepubliceerd. Daartegen verzet het beginsel van vertrouwelijkheid en geheimhouding zich in ieder geval niet. $^{41}$

\subsection{Stel regels om partijen te dwingen het voorschot te betalen}

De oude en de nieuwe arbitragewet bepalen niets over de kosten van de arbitrage. Of er nu sprake is van een ad hoc arbitrage of een institutionele arbitrage, in de regel moet daarvoor een voorschot worden betaald. In ad hoc arbitrages zullen arbiters dat specifiek verlangen als onderdeel van hun opdracht. In het geval van institutionele arbitrage voorziet het toepasselijke arbitragereglement hiertoe in de regel. Ingevolge art. 55 NAI Arbitragereglement moet de eiser het voorschot betalen. De verweerder hoeft in beginsel alleen een voorschot te betalen als hij een tegenvordering instelt. Op grond van veel andere reglementen - vergelijk bijvoorbeeld art. 37 lid 2 ICC Arbitration Rules en art. 43 lid 2 UNCITRAL Arbitration Rules - moeten eiser en verweerder in de regel beiden de helft van het voorschot betalen. In de praktijk gebeurt het echter geregeld dat de verweerder dat nalaat. In plaats van dat de verweerder alsdan het recht wordt ontzegd om verweer te voeren, is de eiser, om te voorkomen dat de arbitrage wordt geschorst of beëindigd, ${ }^{42}$ veelal verplicht ook het deel van de verweerder te betalen. ${ }^{43}$ Niet ongeregeld gaat het om substantiële bedragen. Dit wordt als bijzonder onredelijk ervaren en daar valt wel iets voor te zeggen. ${ }^{44}$ In het geval van overheidsrecht-

40. Zie bijv. EHRM 10 februari $1983,7299 / 75$ en $7496 / 76$ en $7496 / 76$ (Albert en Le Compte/België) en EHRM 21 februari 1990, 11855/85 (Håkansson en Sturesson/Zweden). Zie hierover ook de Guide on Article 6 of the European Convention on Human Rights, p. 65-66, te vinden op: www.echr.coe.int/Documents/Guide_Art_6_ENG.pdf. Vgl. tevens HR 20 mei 1988, NJ 1989/676, m.nt. Alkema en Maeijer (Koster/curator Kobo).

41. Zie ook art. 29 lid 4 Rv.

42. Zie bijv. art. 37 lid 6 ICC Arbitration Rules en art. 43 lid 4 UNCITRAL Arbitration Rules.

43. In de praktijk wordt ook wel eens een order van een scheidsgerecht gezocht of een rechter geadieerd voor een veroordeling van de verweerder tot betaling van het voorschot. Zelfs als deze route uiteindelijk succesvol is, loopt de arbitrage in ieder geval vertraging op.

44. Het kan ook gebeuren dat een eiser het voorschot onbetaald laat, maar dit wordt in de regel niet als een probleem ervaren. spraak wordt toch ook niet van de eiser verwacht dat hij het griffierecht voor de gedaagde partij voorschiet? Aan de andere kant kan ik mij ook wel voorstellen dat een verweerder weinig genegen zal zijn om het voorschot te betalen wanneer hij van mening is dat een geldige arbitrageovereenkomst ontbreekt. Voor dat geval zou ik als best practice willen aanbevelen om, voor zover mogelijk en geïndiceerd, eerst en alleen te beslissen over de bevoegdheid en van eiser enkel een voorschot te vragen ter dekking van de kosten voor die beslissing. ${ }^{45}$ Wanneer de bevoegdheid wordt aangenomen of de bevoegdheid van het scheidsgerecht niet is betwist - in welk geval in beginsel moet worden aangenomen dat een geldige arbitrageovereenkomst bestaat - kan worden geoordeeld dat de verweerder in strijd handelt met zijn verplichtingen uit hoofde van de arbitrageovereenkomst als hij het voorschot niet betaalt. Naar mijn mening moet de verweerder, behoudens afwijkende afspraken tussen partijen, ${ }^{46}$ dan het recht verliezen om verweer te voeren. Die situatie kan gelijk worden gesteld met de situatie waarin verweerder geen verweer voert. De vorderingen van de eiser kunnen dan overeenkomstig art. 1043a lid 2 en $3 \mathrm{Rv}$ onmiddellijk worden toegewezen, tenzij deze aan het scheidsgerecht onrechtmatig of ongegrond voorkomen. Ik zie overigens wel een uitzondering voor het geval de verweerder het voorschot niet kan betalen, omdat er voor hem dan de facto geen rechtsgang zou openstaan, hetgeen onredelijk bezwarend is als bedoeld in art. 6:248 $\mathrm{BW}$ en/of strijd oplevert met art. 6 EVRM. ${ }^{47}$ Speelt die uitzondering niet, dan wordt het beginsel van hoor en wederhoor in ieder geval niet snel geschonden, omdat de verweerder in voornoemde situatie in strijd handelt met de arbitrageovereenkomst, het wettelijk is verankerd dat de verweerder, bij gebreke van een afwijkende afspraak, zijn recht verliest om verweer te voeren, en de verweerder het door het achterwege laten van de vereiste betaling aan zichzelf te wijten heeft dat hij geen verweer kan voeren.

\subsection{Verruim Kompetenz-Kompetenz ten gunste van arbiters}

Het principe van Kompetenz-Kompetenz houdt kort gezegd in dat het scheidsgerecht bevoegd is over zijn eigen bevoegdheid te oordelen. Dit principe is algemeen geaccepteerd. In Nederland is het gecodificeerd in art. 1052 lid 1 Rv. Deze bepaling sluit echter niet uit dat bij de gewone rechter een procedure aanhangig wordt gemaakt waarin de vraag naar het bestaan en de geldigheid van de arbitrageovereenkomst aan de orde komt. Alsdan kunnen twee situaties worden onderscheiden. In de

45. $\mathrm{Nu}$ is het vaak zo dat bij aanvang van de arbitrage een inschatting word gemaakt van de kosten voor de gehele procedure en conform die inschatting een voorschot wordt gevraagd.

46. Aldus hebben partijen ook de mogelijkheid en flexibiliteit om anders overeen te komen, maar geldt er tegelijkertijd een vangnetbepaling voor het geval partijen hieromtrent niets zijn overeengekomen.

47. Dat geldt overigens ook in gevallen waarin de eiser het voorschot niet kan betalen en aldus voor hem de facto geen rechtsgang openstaat. Zie hieromtrent bijv. Hof 's-Hertogenbosch 17 maart 2009, NJF 2009/285, Hof Amsterdam 3 juni 2014, ECLI:NL:GHAMS:2014:2270, waar het recht van Liechtenstein was toegepast, alsmede Rb. Den Haag 12 juli 2017, ECLI:NL:RBDHA:2017:9508. Zie daarnaast bijv. Hof Den Haag 28 november 2017, ECLI:NL:GHDHA:2017:3933. 
eerste situatie wordt de gewone rechter aangezocht als er al een arbitrage aanhangig is of is geweest. In de tweede situatie is er nog geen arbitrage aanhangig op het moment dat de procedure bij de gewone rechter aanhangig wordt gemaakt.

Voor het geval er reeds een arbitrage aanhangig is of is geweest tussen dezelfde partijen over hetzelfde onderwerp laat de wet in het midden wat er moet gebeuren. Indien het scheidsgerecht reeds over zijn bevoegdheid heeft beslist en zich bevoegd heeft verklaard, ligt het voor de hand dat de rechter dat oordeel in beginsel volgt als een van de partijen daarop een uitdrukkelijk beroep doet en zich onbevoegd verklaart dan wel de procedure aanhoudt in afwachting van de uitkomst van een eventuele vernietigingsprocedure. ${ }^{48}$ Als het scheidsgerecht nog niet heeft beslist over zijn bevoegdheid, ligt het in de rede dat de rechter zijn beslissing over zijn bevoegdheid op grond van art. 1022 of $1074 \mathrm{Rv}$ dan wel art. II lid 3 NYC aanhoudt in afwachting van de beslissing van het scheidsgerecht. ${ }^{49}$ Als het prima facie nochtans evident is dat een geldige arbitrageovereenkomst ontbreekt, waaronder tevens de situatie begrepen moet worden dat de voorliggende kwestie niet arbitrabel is, kan de gewone rechter wel bevoegdheid aannemen en de zaak inhoudelijk afdoen. Het kan ook gebeuren dat voor één of meer vorderingen geldig arbitrage is overeengekomen en voor één of meer vorderingen de gewone rechter bevoegd is. Welke vordering dan het eerst moet worden beslecht, is afhankelijk van de feiten en omstandigheden van het geval en hoe de verschillende vorderingen op elkaar ingrijpen. ${ }^{50}$

Is er nog geen arbitrage aanhangig op het moment dat de gewone rechter wordt aangezocht, dan zal deze op grond van art. 1022 of $1074 \mathrm{Rv}$ dan wel art. II lid 3 NYC moeten beslissen of er een geldige arbitrageovereenkomst bestaat. Die beslissing is vervolgens vatbaar voor appel en cassatie. Er kan derhalve enige tijd overheen gaan voordat een definitief oordeel wordt verkregen van de gewone rechter over de geldigheid van de arbitrageovereenkomst. Niets staat er evenwel aan in de weg dat een arbitrage wordt geëntameerd hangende de procedure bij de gewone rechter. Meent het scheidsgerecht dat het bevoegd is, dan kan het de zaak ook inhoudelijk afdoen. Tegenstrijdige uitspraken kunnen dan worden gewezen. Ligt de plaats van arbitrage buiten Nederland en wordt het arbitraal vonnis in de plaats van arbitrage niet vernietigd, dan kan een Nederlandse gerechtelijke uitspraak mogelijk nog een rol spelen als de erkenning en tenuitvoerlegging van dat arbitraal vonnis in Nederland worden gezocht. Ligt de plaats van arbitrage in Nederland, dan is de Nederlandse rechter bevoegd om kennis te nemen van een vernietigingsvordering. ${ }^{51}$ Het is dan aan deze rechter om met inachtneming van de gestelde feiten en omstandigheden te beslissen. De vernietigingsrechter heeft aldus het laatste woord over bijvoorbeeld het bestaan van een geldige arbitrageovereenkomst. Waar de vernietigingsrechter daarbij niet gebonden is aan het oordeel van het scheidsgerecht, ${ }^{52}$ rijst de vraag of hij wel gebonden behoort te zijn aan het oordeel van de gewone rechter, of dat hij zijn eigen afweging dient te maken. In dat verband kunnen verschillende situaties worden onderscheiden. Zo kan het oordeel van het scheidsgerecht dat een geldige arbitrageovereenkomst bestaat, worden genomen voor- of nadat de gewone rechter een finale beslissing wijst. Voor het geval het scheidsgerecht zich niets gelegen heeft laten liggen aan een eerdere beslissing van de gewone rechter, die kracht van gewijsde heeft gekregen, waarbij is geoordeeld dat een geldige arbitrageovereenkomst ontbreekt, wordt wel verdedigd dat de eerdere beslissing van de gewone rechter, indien daarop een beroep wordt gedaan, in de vernietigingsprocedure gezag van gewijsde heeft. ${ }^{53}$ Zou men deze opvatting volgen, dan ondermijnt men wel het principe van Kompetenz-Kompetenz en ontneemt men de vernietigingsrechter bovendien de bevoegdheid om zijn eigen afweging te maken. Dat geldt mogelijk te meer in de situatie dat het scheidsgerecht over zijn bevoegdheid beslist voordat de gewone rechter met kracht van gewijsde oordeelt dat een geldige arbitrageovereenkomst ontbreekt. Ik kan mij nochtans voorstellen dat het arbitraal vonnis wordt vernietigd als de rechter van de plaats van arbitrage (lees: het gerechtshof van het ressort waarin de plaats van arbitrage is gelegen) reeds met kracht van gewijsde heeft geoordeeld dat een geldige arbitrageovereenkomst ontbreekt. Gezien het voorgaande is dan ook voorstelbaar dat scheidsgerechten genegen zullen zijn de zaak aan te houden hangende de procedure bij de gewone rechter. Naar mijn idee zal een scheidsgerecht hiertoe echter niet te snel moeten overgaan. In bijvoorbeeld Zwitserland is het wettelijk uitgangspunt dat de arbitrage in beginsel wordt voortgezet. ${ }^{54}$

Als de arbitrage wordt voortgezet hangende de procedure bij de gewone rechter, ontstaat, zoals ik hiervoor heb uiteengezet, een samenloop van procedures en bestaat het risico van tegenstrijdige uitspraken. Deze anomalie kan worden voorkomen door het scheidsgerecht te verplichten de arbitrage aan te houden hangende de procedure bij de gewone rechter, maar dat

48. Als het arbitraal vonnis wordt vernietigd, geldt art. 1067 Rv. Zie ook voetnoot 58 .

49. Vgl. Rb. Den Haag 19 mei 2004, JBPR 2004/63, m.nt. Meijer (Zuivelschap Hollandse Eilanden en Waarden c.s./BAM), Rb. Rotterdam 21 februari 2007, ECLI:NL:RBROT:2007:BG9289 (Mitsui/Irina) en G.J. Meijer, Overeenkomst tot arbitrage: bezien in het licht van het bewijsvoorschrift van artikel $1021 \mathrm{Rv}$, Deventer: Kluwer 2011 (hierna: Meijer 2011), p. 898-899.

50. Zie bijv. HR 26 november 2010, NJ 2011/55, m.nt. Schilfgaarde (Silver Lining).

51. Zie art. 1064 a lid $1 \mathrm{Rv}$

52. HR 26 september 2014, NJ 2015/318, m.nt. Snijders (Ecuador/Chevron \& Texaco).

53. Aldus Meijer 2011, p. 983.

54. Zie art. 186 lid 1 bis van het Bundesgesetz über das Internationale Privatrecht (BIP). Dit artikel bepaalt dat het scheidsgerecht 'entscheidet über seine Zuständigkeit ungeachtet einer bereits vor einem staatlichen Gericht oder einem anderen Schiedsgericht hängigen Klage über denselben Gegenstand zwischen denselben Parteien, es sei denn, dass beachtenswerte Gründe ein Aussetzen des Verfahrens erfordern'. 
werkt Italiaanse torpedoachtige toestanden in de hand. ${ }^{55}$ Partijen kunnen de arbitrage dan immers jaren vertragen, simpelweg door het aanhangig maken van een gerechtelijke procedure. Dit is derhalve geen adequate oplossing. Het is mijns inziens dan ook beter om prioriteit te geven aan arbiters. Ik zou de gewone rechter derhalve willen verplichten de procedure aan te houden als wordt gesteld dat een arbitrageovereenkomst bestaat, ${ }^{56}$ tenzij het prima facie evident is dat een geldige arbitrageovereenkomst ontbreekt. Als de gewone rechter de procedure aanhoudt, kan het scheidsgerecht onverkort gebruik maken van zijn recht van Kompetenz-Kompetenz. ${ }^{57}$ Verklaart het scheidsgerecht zich bevoegd, dan kan de rechter zich onbevoegd verklaren dan wel de procedure aanhouden in afwachting van de uitkomst van een eventuele vernietigingsprocedure. ${ }^{58}$ Verklaart het scheidsgerecht zich onbevoegd vanwege het ontbreken van een geldige arbitrageovereenkomst, dan kan de procedure bij de gewone rechter worden voortgezet. ${ }^{59}$ Wanneer voor één of meer vorderingen op geldige wijze arbitrage is overeengekomen en voor één of meer vorderingen de gewone rechter bevoegd is, geldt hetgeen ik daarover hiervoor heb geschreven.

\subsection{Beperk vernietigingsprocedure tot één instantie}

Wanneer partijen arbitrage overeenkomen, hebben zij in beginsel slechts één feitelijke instantie om hun feiten en argu-

55. Onder de Brussel I-Verordening kon de partij die binnen afzienbare tijd een claim van haar wederpartij verwachtte, een zaak aanhangig maken bij bijvoorbeeld de Italiaanse rechter, wetende dat de Italiaanse rechter lange tijd nodig heeft om een oordeel over zijn bevoegdheid te geven. Al die tijd kon de zaak niet worden beslecht door andere lidstaatrechters bij wie de zaak werd aangebracht, ook niet als er sprake was van een exclusieve forumkeuze. De andere lidstaatrechters moesten namelijk eerst het oordeel van de Italiaanse rechter over zijn bevoegdheid afwachten. In de Brussel Ibis-Verordening is de Italiaanse torpedo nu gedeeltelijk ontmanteld met de invoering van art. 31 lid 2. De forumkeuzerechter heeft nu voorrang.

56. Voor het geval de arbitrage nog niet aanhangig is, komt het mij voor dat de procedure bij de gewone rechter in eerste instantie voor een korte periode moet worden aangehouden om de meest gerede partij de gelegenheid te geven een arbitrage te entameren. Indien daarmee in gebreke wordt gebleven, kan de gerechtelijke procedure worden voortgezet.

57. Zie hierover E. Gaillard \& Y. Banifatemi, 'Negative effect of competence-competence: The rule of priority in favour of the arbitrators', in: E. Gaillard, D. di Pietro \& N. Leleu-Knobil (red.), Enforcement of arbitration agreements and international arbitral awards: The New York Convention in practice, Londen: Camaron May 2008, p. 257-273, met een verwijzing naar buitenlandse rechtsstelsels waar eveneens prioriteit wordt gegeven aan arbiters. Zie voorts art. 1448 CPC: 'Lorsqu'un litige relevant d'une convention d'arbitrage est porté devant une juridiction de l'Etat, celle-ci se déclare incompétente sauf si le tribunal arbitral n'est pas encore saisi et si la convention d'arbitrage est manifestement nulle ou manifestement inapplicable. La juridiction de l'Etat ne peut relever d'office son incompétence. Toute stipulation contraire au présent article est réputée non écrite.'

58. Zou de gewone rechter zich onbevoegd verklaren, dan krijgt deze beslissing geen gezag van gewijsde, nu deze zich slechts ter vermijding van tegenstrijdige beslissingen onbevoegd verklaart. In zoverre kan ook de vergelijking worden gemaakt met de litispendentieregeling van bijvoorbeeld art. $12 \mathrm{Rv}$ en art. 29 e.v. Brussel Ibis-Verordening. Na vernietiging van het arbitraal vonnis kan vervolgens onder omstandigheden een nieuwe procedure bij de gewone rechter aanhangig worden gemaakt. Vgl. art. $1067 \mathrm{Rv}$.

59. Zie ook art. 1052 lid 5 Rv. menten te presenteren. Dat wordt in de regel als een voordeel gezien, maar daarmee eindigt het geschil niet per se. De partij die zich niet kan verenigen met de uitkomst van de arbitrage kan ingevolge art. $1064 \mathrm{Rv}$ immers een vernietigingsprocedure entameren. ${ }^{60}$ Waar deze procedure voorheen aanhangig moest worden gemaakt bij de rechtbank, dient die procedure per 1 januari 2015 op grond van art. 1064 a lid $1 \mathrm{Rv}$ aanhangig te worden gemaakt bij het gerechtshof van het ressort waarin de plaats van arbitrage is gelegen. De wetgever heeft de vernietigingsprocedure met een instantie verkort om te voorkomen dat partijen na het doorlopen van de arbitrage nog veel geld en tijd kwijt zijn. ${ }^{61}$ Het geding bij het gerechtshof moet zo veel mogelijk worden gevoerd in overeenstemming met de bepalingen die van toepassing zijn op een dagvaardingsprocedure in eerste aanleg. ${ }^{62}$ Cassatie is vervolgens mogelijk, zij het dat professionele partijen cassatie op grond van art. 1064a lid $5 \mathrm{Rv}$ kunnen uitsluiten om de vernietigingsprocedure met nog een instantie te verkorten. ${ }^{63}$ Voor zover ik heb kunnen nagaan, wordt van deze mogelijkheid niet of nauwelijks expliciet gebruik gemaakt. De bekende arbitrage-instituten geven deze optie ook niet bij hun modelclausule. Als cassatie niet wordt uitgesloten, kan een vernietigingsprocedure in twee instanties, opeenvolgend bij het bevoegde gerechtshof en de Hoge Raad, zo drie tot vier jaar duren (zelfs in gevallen waarin de Hoge Raad de zaak uiteindelijk afdoet op grond van art. 80a of 81 lid 1 van de Wet op de rechterlijke organisatie).

Lange vernietigingsprocedures worden in de praktijk als een groot ongemak ervaren. ${ }^{64} \mathrm{Om}$ die reden heeft men in Zwitserland bepaald dat het Bundesgericht in nationale arbitrages in beginsel beslist over een vordering tot vernietiging en in internationale arbitrages wat dat betreft exclusief bevoegd is. ${ }^{65}$ Aldus krijgt men gelijk een oordeel van de hoogste rechter, veelal binnen zes tot twaalf maanden. Dit wordt als zeer positief ervaren en het draagt mede bij aan de populariteit van Zwitserland als plaats van arbitrage. In navolging van Zwitserland heeft Oostenrijk een soortgelijke regel ingevoerd. Vernietigingsprocedures moeten in Oostenrijk aanhangig worden gemaakt bij het Oberste Gerichtshof. ${ }^{66}$ Wat mij betreft zou zo'n regel ook in Nederland mogen worden ingevoerd. Ik weet

60. Als het scheidsgerecht één of meer gedeeltelijke eindvonnissen heeft gewezen, worden er mogelijk zelfs meerdere vernietigingsprocedures geëntameerd, terwijl niets eraan in de weg staat dat het scheidsgerecht de arbitrage hangende de vernietigingsprocedure(s) voortzet, hetgeen in de regel ook gebeurt. Dit is naar mijn idee weinig efficiënt. Als men vindt dat de arbitrage niet van rechtswege moet worden geschorst op het moment dat een vernietigingsprocedure wordt geëntameerd, lijkt het mij beter om wettelijk te verankeren dat een vernietigingsprocedure alleen kan (en hoeft te) worden geëntameerd nadat het arbitraal eindvonnis is gewezen. Dit voorkomt een samenloop van procedures, met alle negatieve gevolgen van dien.

61. Kamerstukken II 2012/13, 33611, 3, p. 2 en 38 (MvT).

62. Hof Amsterdam 10 juli 2018, ECLI:NL:GHAMS:2018:2385.

63. Kamerstukken II 2012/13, 33611, 3, p. 39 (MvT) en Kamerstukken II 2013/14, 33611, 5, p. 16-18 (NV).

64. Peters 2017, p. 49.

65. Art. 389-390 Schweizerische Zivilprozessordnung respectievelijk art. 191 BIP.

66. Art. 615 Österreichisches Zivilprozessordnung. 
alleen niet of onze Hoge Raad er nu op zit te wachten dat vernietigingsprocedures gelijk bij hem aanhangig kunnen worden gemaakt. ${ }^{67}$

Bij wijze van alternatief zou men de mogelijkheid van cassatie wettelijk kunnen uitsluiten of een opt-inmodel kunnen instellen. Cassatie is dan alleen mogelijk als partijen dat uitdrukkelijk zijn overeengekomen. Als men zover niet wil gaan, biedt het Zweedse model een werkbaar alternatief. ${ }^{68}$ Ingevolge art. 43 lid 1 van de Zweedse Arbitragewet moet een vernietigingsprocedure aanhangig worden gemaakt bij het gerechtshof van de plaats van arbitrage. ${ }^{69}$ Cassatie is alleen mogelijk na verlof van het gerechtshof, dat slechts verplicht is dat verlof te verlenen als het voor de rechtsontwikkeling belangrijk is dat de Zweedse Högsta domstolen, de Zweedse hoogste rechter, een beslissing wijst. In veel gevallen speelt dit echter niet. Daardoor blijft de vernietigingsprocedure in de meerderheid van de gevallen beperkt tot één instantie.

\subsection{Geefpartijen de mogelijkheid om vernietiging bij rechter uit te sluiten}

De Nederlandse wet voorziet niet in de mogelijkheid om vernietiging uit te sluiten. ${ }^{70}$ De wetgever is namelijk van mening dat de mogelijkheid een vordering tot vernietiging in te stellen het vertrouwen in arbitrage stut. ${ }^{71}$ Op grond van bijvoorbeeld de Belgische, Franse en Zwitserse arbitragewet kan vernietiging wel worden uitgesloten. In België mag vernietiging worden uitgesloten als geen van de partijen de Belgische nationaliteit heeft en partijen hun woonplaats, gewone verblijfplaats, statutaire zetel, voornaamste vestiging of bijkantoor evenmin in België hebben. ${ }^{72}$ In Zwitserland wordt verlangd dat geen van de partijen haar woonplaats, gewone verblijfplaats of handelsvestiging in Zwitserland heeft. ${ }^{73}$ In Frankrijk is vereist dat het gaat om een internationale arbitrage als bedoeld in art. 1504 CPC. ${ }^{74}$ Onze Hoge Raad erkent de geldigheid van een uitsluitingsbeding ook, indien dat beding geldig is naar het recht van de plaats van arbitrage en strookt met de vereisten van art. 6 EVRM, ${ }^{75}$ welk artikel zich er niet principieel tegen verzet dat partijen afstand doen van hun recht op een vernietigingsprocedure. ${ }^{76}$ Naar mijn mening moet vernie-

67. Hierbij zij volledigheidshalve opgemerkt dat in de NV (Kamerstukken II 2013/14, 33611, 5) werd gemeld dat er jaarlijks gemiddeld tussen de twintig en dertig nieuwe vernietigingsprocedures aanhangig worden gemaakt.

68. Zie ook F. De Ly, 'De herziening van de Arbitragewet en de internationale arbitrage', $T v A 2005 / 35$, p. 62.

69. Op grond van het wetsvoorstel dat thans voorligt, zal alleen het gerechtshof te Stockholm (de Svea hovrätt) nog bevoegd zijn om te beslissen op vernietigingsvorderingen.

70. Zie ook Kamerstukken II 2013/14, 33611, 5, p. 18 (NV). Daar stelt de wetgever dat het partijen niet vrijstaat afstand te doen van de vernietigingsprocedure.

71. Kamerstukken II 2012/13,33611, 3, p. 38 (MvT).

72. Art. 1718 BGW.

73. Art. 192 BIP.

74. Art. $1522 \mathrm{CPC}$

75. HR 1 mei 2015, NJ 2015/454, m.nt. Strikwerda (Çukurova/Sonera).

76. Zie in gelijke zin Snijders, in: GS Rv 2018, art. $1064 \mathrm{Rv}$, aant. 1. Zie voor de voorwaarden waaraan moet worden voldaan voor een geldige uitsluitingsovereenkomst nader M.W. Knigge \& P.L.F. Ribbers, 'Arbitrage, afstand van recht en art. 6 EVRM', TvA 2017/20. tiging ook in Nederland kunnen worden uitgesloten, in ieder geval wanneer de partijen bij de arbitrage in Nederland woonachtig noch gevestigd zijn. ${ }^{77}$ In dat geval blijft rechterlijke controle door de exequaturrechter en deze zal het exequatur op grond van art. $1063 \mathrm{Rv}$ (moeten) kunnen weigeren als een van de vernietigingsgronden zich voordoet, bijvoorbeeld als het arbitraal vonnis in strijd is met de Nederlandse openbare orde. Er bestaat aldus een systeem van checks and balances waarmee wordt voorkomen dat arbitrale vonnissen die de toets der kritiek in het geval van een vernietigingsprocedure niet hadden kunnen doorstaan toch in Nederland ten uitvoer kunnen worden gelegd.

Tegelijkertijd leert de ervaring dat bij partijen een zekere terughoudendheid bestaat om vernietiging geheel uit te sluiten, al willen partijen wel vaak de inmenging van de overheidsrechter beperken, bijvoorbeeld om te voorkomen dat de vertrouwelijkheid wordt doorbroken. Om deze reden heb ik in 2012 bepleit dat partijen de mogelijkheid moeten hebben om in plaats van een vernietigingsprocedure bij de gewone rechter te opteren voor een vernietigingsprocedure bij een scheidsgerecht. ${ }^{78}$ Dat scheidsgerecht beslist dan met inachtneming van de vernietigingsgronden van art. $1065 \mathrm{Rv}^{79}$

\subsection{De exequaturprocedure moet in eerste instantie altijd exparte}

Op grond van art. 1062 lid $1 \mathrm{Rv}$ is de voorzieningenrechter bevoegd om kennis te nemen van verzoeken ter verkrijging van een exequatur op een Nederlands arbitraal vonnis. Deze procedure is in beginsel exparte. Nochtans kunnen partijen de voorzieningenrechter per brief verzoeken om te worden gehoord. Het is vervolgens aan de voorzieningenrechter om dat verzoek wel of niet toe te staan, ${ }^{80}$ maar in mijn ervaring wordt zo'n verzoek al snel toegestaan als het uitvoerig is gemotiveerd. Gaat het om de erkenning en tenuitvoerlegging van een buitenlands arbitraal vonnis, dan is het gerechtshof bevoegd. ${ }^{81}$ De wederpartij heeft alsdan zonder meer het recht een verweerschrift in te dienen en een zitting vindt in beginsel plaats. In alle gevallen vergt het inplannen van een zitting tijd. Waar zittingen bij de voorzieningenrechter meestal nog kunnen plaatsvinden binnen enkele weken tot maanden, worden zittingen bij de gerechtshoven veelal ingepland op een termijn van drie tot zes maanden of meer. ${ }^{82}$ Vervolgens gaat er

77. In Nederland is de mogelijkheid van uitsluiting bijvoorbeeld eerder bepleit door D.A.M.H.W. Strik \& J.B.J. Hoefnagel, 'Uitsluitingsovereenkomsten en het consultatie-wetsontwerp herziening arbitragewetgeving: een gemiste kans?', TvA 2012/20.

78. N. Peters, 'Vernietiging van arbitrale vonnissen door ad-hocscheidsgerechten, is dat niet vernieuwend?', in: Piet Sanders: een honderdjarige vernieuwer, Den Haag: Boom Juridische uitgevers 2012, p. 217-223.

79. Voor een meer gedetailleerde beschouwing hierover zij verwezen naar voornoemde publicatie.

80. Zie ook Meijer, in: T\&C Rv 2018, art. 1062 Rv, ant. 3(c).

81. Zie art. 987 lid $1 \mathrm{Rv}$.

82. Zie art. 1075 lid 2 en 1076 lid 6 Rv. Onder de oude arbitragewet was de voorzieningenrechter ook bevoegd ten aanzien van buitenlandse arbitrale vonnissen, maar bij de nieuwe wet is dit het gerechtshof geworden om de exequaturprocedure gelijk de vernietigingsprocedure met een instantie te verkorten. Zie hieromtrent nader Kamerstukken II 2013/14, 33611,5 , p. 19 (NV). 
nog enige tijd overheen voordat een beschikking wordt gewezen. Zulke lange doorlooptijden zijn nauwelijks te rechtvaardigen als men zich bedenkt dat het exequatur in het gros van de gevallen wordt verleend. Lange doorlooptijden worden dan ook als hinderlijk ervaren.

Een eenvoudige oplossing is voorhanden als in eerste instantie altijd ex parte wordt beslist (zoals dat nu ook gebeurt bij ICSID-vonnissen). Verlof tot tenuitvoerlegging kan dan binnen één tot enkele dagen worden verleend. Wordt een exequatur verleend op een Nederlands arbitraal vonnis, dan dient appel bij het gerechtshof mogelijk te zijn als vernietiging kan worden uitgesloten en partijen dat zijn overeengekomen. Gaat het om een exequatur op een buitenlands arbitraal vonnis, dan moet de partij die zich niet met de beslissing kan verenigen wel de mogelijkheid hebben om daartegen in verzet te komen bij het gerechtshof dat op het verzoek heeft beslist. Een soortgelijke regeling kent men bijvoorbeeld in Frankrijk. ${ }^{83}$ Omdat mag worden aangenomen dat lang niet in alle gevallen een rechtsmiddel zal worden ingesteld, wordt met deze oplossing in het algemeen een substantiële verkorting van de exequaturprocedure bewerkstelligd. ${ }^{84}$

\subsection{Schep ruime mogelijkheid om gerechtelijke procedures in het Engels te voeren}

Arbitrages met internationale kenmerken worden veelal in de Engelse taal gevoerd, terwijl procedures bij de overheidsrechter in verband met arbitrage in beginsel in de taal van die rechter worden gevoerd. Dit wordt als ongemakkelijk ervaren en er bestaat dan ook behoefte om in het Engels te kunnen procederen. De wetgever is aan deze wens tegemoetgekomen, in die zin dat een vordering tot vernietiging na de oprichting van de Netherlands Commercial Court of Appeal aan deze kan worden voorgelegd, ${ }^{85}$ mits (1) het gaat om een internationaal geschil als bedoeld in art. 30r Rv, (2) de plaats van arbitrage in het ressort Amsterdam is gelegen, en (3) partijen hierin bij overeenkomst uitdrukkelijk hebben voorzien. ${ }^{86}$

Wat mij betreft gaat het wetsvoorstel niet ver genoeg. Zo zie ik niet in waarom niet meer procedures die verband houden met arbitrage - bijvoorbeeld voor de herziening van het arbitraal vonnis - in het Engels kunnen worden gevoerd. Verder heb ik er moeite mee dat op grond van de tekst van het wetsvoorstel slechts in het Engels kan worden geprocedeerd als de plaats van arbitrage in het ressort van het Gerechtshof Amsterdam is gelegen. In veel gevallen ligt de plaats van arbitrage namelijk buiten dat ressort, bijvoorbeeld in Den Haag of Rotterdam, waar de Permanent Court of Arbitration respectievelijk het NAI zijn gevestigd.

83. Vgl. bijv. art. 1516 en 1522 CPC.

84. Als dezelfde regel wordt ingevoerd voor procedures waar alleen om erkenning van het arbitraal vonnis wordt verzocht, geldt daarvoor hetzelfde.

85. Ook in bijv. Zweden en Zwitserland zijn wetsvoorstellen aanhangig om het mogelijk te maken in vernietigingsprocedures in het Engels te procederen.

86. Zie Kamerstukken II 2016/17, 34761, 2 (voorstel van wet) en 3, p. 15 (MvT).
Omdat ik mij kan voorstellen dat de wetgever niet genegen zal zijn om bij alle gerechten het Engels als voertaal toe te staan, zou ik willen voorstellen om de (voorzieningenrechter van de) Rechtbank Amsterdam respectievelijk het Gerechtshof Amsterdam bij uitsluiting bevoegd te verklaren voor procedures in verband met arbitrage, zodat in alle gevallen gebruik kan worden gemaakt van de diensten van de $\mathrm{NCC}(\mathrm{A}) .{ }^{87} \mathrm{Bij}-$ komend voordeel is dat bij deze gerechten ook specifieke kennis kan worden opgebouwd. Daar zijn de rechtspraak en de rechtszekerheid bij gebaat. ${ }^{88}$

Zou men voornoemde gerechten inderdaad exclusief bevoegd verklaren, dan kan ook als regel worden vastgelegd dat de procedure bij de $\mathrm{NCC}(\mathrm{A})$ plaatsvindt als de arbitrage in het Engels heeft plaatsgevonden, tenzij een van de partijen opt-out. Ik vind deze regel te rechtvaardigen als in ogenschouw wordt genomen dat partijen ten behoeve van de arbitrage veelal reeds een bewuste keuze voor het Engels hebben gemaakt en in geval van een procedure bij de NCC(A) de vertaalkosten en de kosten van een tolk kunnen worden uitgespaard, zodat de hogere griffiekosten (grotendeels) worden gecompenseerd. Wil een partij desalniettemin niet in het Engels procederen bij de NCC(A), dan kan zij altijd nog gebruik maken van haar recht van opt-out. Aldus wordt niemand gedwongen om tegen zijn wil in het Engels te procederen.

\subsection{Voer dualistisch stelsel in}

In Nederland heeft de wetgever gekozen voor een monistisch stelsel, waarbij in beginsel geen onderscheid wordt gemaakt tussen nationale en internationale arbitrage. Bij de invoering van de arbitragewet van 1986 heeft de wetgever voor een monistisch stelsel gekozen, omdat een definitie wat onder internationale arbitrage moet worden verstaan te allen tijde vragen zou doen rijzen. ${ }^{89} \mathrm{Bij}$ de invoering van de nieuwe arbitragewet heeft de wetgever in navolging van het ontwerp van Van den Berg gekozen voor continuïteit en ingeburgerde traditie. $^{90}$ Snijders juicht dit toe. Volgens hem zijn er in het algemeen namelijk geen goede gronden om nationale en internationale arbitrage te onderscheiden en zouden pogingen in andere landen om de concurrentiepositie te verbeteren door de invoering van een dualistisch stelsel, waarbij wel wordt onderscheiden tussen nationale en internationale arbitrage,

87. Als de wetgever zou willen vasthouden aan zijn idee om het Engels als procestaal alleen toe te staan in het kader van vernietigingsprocedures, zou de wetgever ook kunnen overwegen om (1) de eis te laten vallen dat de plaats van arbitrage gelegen moet zijn in het ressort Amsterdam, en (2) partijen in afwijking van het huidige art. 1064a lid $1 \mathrm{Rv}-$ dat onder meer een dwingende regel voor relatieve bevoegdheid bevat (Kamerstukken II 2012/13, 33611, 3, p. 38 (MvT)) - de mogelijkheid te geven om een vernietigingsprocedure aanhangig te maken bij het Gerechtshof Amsterdam, opdat deze procedure, ongeacht de plaats van arbitrage, in het Engels kan worden gevoerd bij de Netherlands Commercial Court of Appeal.

88. P. Sanders, 'Herziening van onze arbitragewet', TvA 2008/15, p. 45-46.

89. Zie hieromtrent Kamerstukken II 1983/84, 18464, 3, p. 1 (MvT).

90. In de toelichting op zijn ontwerp (TvA2005/37, p. 127) betoogde Van den Berg dat er geen aanleiding bestond het monistisch uitgangspunt te verlaten. 
geen bewijsbare successen hebben geoogst. ${ }^{91}$ Ik vind het echter opvallend dat drie van de populairste arbitragelanden - Frankrijk, Zwitserland en Singapore - wel een dualistisch stelsel kennen. Een dualistisch stelsel schaadt de concurrentiepositie in ieder geval dus niet.

Wil men nationale en internationale arbitrage onderscheiden, dan moet duidelijk worden gedefinieerd wanneer er sprake is van een internationale arbitrage. In de praktijk worden verschillende criteria gehanteerd. In Zwitserland wordt bijvoorbeeld aansluiting gezocht bij geografische criteria. Een arbitrage wordt aldaar als internationaal gekwalificeerd als ten tijde van het sluiten van de arbitrageovereenkomst de woonof vestigingsplaats van een van de partijen buiten Zwitserland ligt. ${ }^{92}$ Frankrijk hanteert op zijn beurt een materieel criterium, waar een arbitrage internationaal is in gevallen 'met en cause des intérêts du commerce international'. ${ }^{93}$ Op grond van de Modelwet is er sprake van een internationale arbitrage als: ${ }^{94}$

'a. the parties to an arbitration agreement have, at the time of the conclusion of that agreement, their places of business in different States; or

b. one of the following places is situated outside the State in which the parties have their places of business:

i. the place of arbitration if determined in, or pursuant to, the arbitration agreement;

ii. any place where a substantial part of the obligations of the commercial relationship is to be performed or the place with which the subject-matter of the dispute is most closely connected; or

c. the parties have expressly agreed that the subject matter of the arbitration agreement relates to more than one country'.

Het moge duidelijk zijn dat een arbitrage op grond van de Franse regel en de Modelwet eerder als internationaal kan worden gekwalificeerd dan op grond van de Zwitserse regel. Daar staat tegenover dat een geografisch criterium in de regel minder discussiegevoelig is. ${ }^{95}$

Een dualistisch stelsel heeft als grootste voordeel dat aan partijen en het scheidsgerecht in geval van internationale arbitrage een grotere mate van vrijheid en flexibiliteit kan worden geboden om de procedure naar eigen inzichten in te richten. Dit wordt bereikt door voor internationale arbitrages een eenvoudigere en minder gedetailleerde regeling met slechts een beperkt aantal basisnormen aan te bieden, waarbij de bepalingen van regelend recht en de bepalingen van dwingend recht,

91. Snijders 2014, p. 94.

92. Art. 176 lid 1 BIP.

93. Art. 1504 CPC.

94. Art. 1 lid 3 Modelwet.

95. Zie hieromtrent Peters 2017, p. 26-28. die niet strikt noodzakelijk zijn, buiten toepassing blijven. ${ }^{96}$ Partijen en het scheidsgerecht hoeven zich in dat geval niet te veel te verdiepen in en te bekommeren om het Nederlands arbitragerecht. Dat vereenvoudigt het procedurele speelveld voor de arbiters en de partijen aanmerkelijk. Daarmee wordt Nederland mogelijk ook interessanter voor buitenlandse partijen die op zoek zijn naar een neutrale plaats van arbitrage.

Ten behoeve van de invoering van een dualistisch stelsel kan eenvoudig een nieuwe titel voor internationale arbitrage aan het Vierde Boek van Rv worden toegevoegd. Aan het begin van die nieuwe titel zal de wetgever dan moeten aangeven wanneer er sprake is van een internationale arbitrage. Mijn voorkeur gaat hier uit naar een geografisch criterium. Met Meijer zou ik aansluiting willen zoeken bij de Zwitserse regel. ${ }^{97}$ Meijer heeft verder voorgesteld om naar Frans model via een algemene schakelbepaling de relevante bepalingen uit de eerste titel (art. 1020-1073 Rv) van toepassing te verklaren op internationale arbitrages. ${ }^{98}$ Persoonlijk denk ik dat het voor het overzicht en het gebruiksgemak beter is als de relevante basisnormen worden opgenomen in de nieuwe titel. Dan is een enkele blik op deze titel voldoende om inzicht te krijgen in het toepasselijke arbitragerecht.

\subsection{Beperk de rol van de voorzieningenrechter niet te veel}

Op grond van art. 1022a en 1074a Rv belet een overeenkomst tot arbitrage niet dat een partij de gewone rechter verzoekt om een maatregel tot bewaring van recht dan wel zich wendt tot de voorzieningenrechter van de rechtbank of de kantonrechter in kort geding overeenkomstig art. $254 \mathrm{Rv}$. Ingevolge art. $1022 \mathrm{c}$ en $1074 \mathrm{~d} \mathrm{Rv}$ moet de aangezochte rechter zich evenwel onbevoegd verklaren als een partij zich voor alle weren beroept op het bestaan van een overeenkomst tot arbitrage, tenzij de gevraagde beslissing niet of niet tijdig in arbitrage kan worden verkregen. ${ }^{99}$ De gedachte van de wetgever hierachter is dat het de voorkeur verdient dat de beslissingen over middelen tot bewaring van recht en voorlopige voorzieningen zo veel mogelijk worden genomen door arbiters. ${ }^{100}$ Hierbij is het volgens de wetgever uitdrukkelijk niet de bedoeling dat de rechter uitvoerig gaat onderzoeken of de arbitrageovereenkomst geldig is, ${ }^{101}$ al behoort de rechter zich niet onbevoegd te verklaren als zonder nader onderzoek evident is dat een geldige arbitrageovereenkomst ontbreekt. Daarbij moet de rechter bijvoorbeeld

96. Een dualistisch stelsel brengt aldus ook mee dat in geval van internationale arbitrage minder snel sprake zal zijn van een samenloop tussen de wettelijke regeling en een arbitragereglement, een partijafspraak of een order van het scheidsgerecht. Zie over deze samenloop Peters 2017, p. 51-54.

97. Meijer 2015, p. 94

98. Zie hieromtrent Meijer 2015, p. 92-94, waar hij ook een voorstel doet voor de artikelen die van toepassing zouden moeten zijn in geval van internationale arbitrage.

99. Zie over het tijdigheidsvereiste onder meer T. Stouten \& L. Stevens, 'Het tijdigheidsvereiste van artikel $1022 \mathrm{c}$ en artikel $1074 \mathrm{~d}$ Rv', Tv $A$ 2016/25.

100. Zie hieromtrent Kamerstukken II 2012/13, 33611, 3, p. 10 (MvT) alsmede Kamerstukken II 2013/14, 33611, 5, p. 20 (NV) en 6, p. 8-9 $(\mathrm{NvW})$.

101. Kamerstukken II $2013 / 14,33611$, 6, p. 8-9 (NvW). 
toetsen of het niet gaat om een oneerlijk beding en de kwestie wel arbitrabel is. ${ }^{102}$

In de praktijk verklaart de rechter zich regelmatig onbevoegd omdat de gevraagde voorzieningen ook tijdig in arbitrage kunnen worden gekregen. ${ }^{103}$ Dat zou ook kunnen gelden in gevallen waarin partijen uitdrukkelijk de mogelijkheid hebben opengehouden om de gewone rechter aan te zoeken voor voorlopige of bewarende maatregelen. Art. 1022c en 1074d Rv bieden partijen namelijk niet de mogelijkheid om anders overeen te komen. Aldus zou gezien de parlementaire geschiedenis kunnen worden betoogd dat het gaat om regels van dwingend recht, waarvan partijen niet kunnen afwijken. ${ }^{104}$ Als deze duiding inderdaad zou moeten worden gevolgd, zijn bijvoorbeeld art. 28 lid 2 en 29 lid 7 ICC Arbitration Rules, art. 9 lid 12 LCIA Arbitration Rules en art. 30 lid 3 SIAC Arbitration Rules, waarin uitdrukkelijk wordt voorzien in de gang naar de gewone rechter voor voorlopige of bewarende maatregelen, zinledig. ${ }^{105}$ Daarmee zou Nederland internationaal gezien dan weer een bijzondere positie innemen.

Hoewel ik in de regel een pleitbezorger ben van zo weinig mogelijk gerechtelijke inbreng in het kader van arbitrage, zou ik voor voorlopige en bewarende maatregelen zonder meer een uitzondering willen maken. Via de voorzieningenrechter kan immers op een efficiënte en kostenvriendelijke wijze op korte termijn een beslissing worden verkregen. Bovendien voorkomt dat discussie of een arbitrageovereenkomst bestaat, of de verzochte middelen wel tijdig in arbitrage kunnen worden verkregen, of een eventuele beslissing van een scheidsgerecht wel voor tenuitvoerlegging in aanmerking komt, enzovoort. Als de plaats van arbitrage in het buitenland ligt en er moet, nadat een arbitrale beslissing is verkregen, een exequatur worden verkregen, dan kan daar, zoals volgt uit paragraaf 2.7 , ook nog best wat tijd overheen gaan. Vanuit kostenoogpunt en doelmatigheidsoverwegingen is het derhalve beter om de gewone rechter (ook) bevoegd te laten zijn als het gaat om voorlopige en bewarende maatregelen, tenzij partijen anders zijn overeengekomen.

\section{Conclusie}

Met het voorgaande heb ik getracht een bijdrage te leveren aan de verdere ontwikkeling van onze arbitragewet. De huidige wet biedt zonder meer een goede basis, maar is weinig innovatief en wijkt op onderdelen af van buitenlandse arbitragewetten. Met voornoemde suggesties wordt onze wet meer in lijn gebracht met populaire buitenlandse arbitragewetten en worden enkele innovaties geïntroduceerd waarmee tegemoet wordt gekomen aan de wensen van de gebruikers van arbitra-

102. In gelijke zin A.D. Josephus Jitta, 'Reactie op: Het tijdigheidsvereiste van artikel 1022c en artikel $1074 \mathrm{~d} \mathrm{Rv}$ in het kort geding', TvA 2016/68, p. 86.

103. Zie Rb. Den Haag 12 juni 2015, ECLI:NL:RBDHA:2015:6959, Rb. Amsterdam 12 januari 2017, ECLI:NL:RBAMS:2017:282 en Rb. Midden-Nederland 7 juni 2017, ECLI:NL:RBMNE:2017:2652.

104. Vgl. Kamerstukken II 2012/13, 33611, 3, p. 5 (MvT).

105. Zie bijv. Rb. Den Haag 12 juni 2015, ECLI:NL:RBDHA:2015:6959 en Rb. Amsterdam 12 januari 2017, ECLI:NL:RBAMS:2017:282. ge. Het zou hoe dan ook mooi zijn als Nederland in de toekomst meer arbitrages zou weten aan te trekken en de Nederlandse concurrentiepositie in die zin verbetert, met alle (economische) voordelen, zoals uiteengezet in de inleiding van dit artikel, van dien. 